\title{
DIE GENADEGAWES IN DIE NUWE TESTAMENT
}

\author{
Deur Ds. G. N. Bloem*
}

\section{GENADEGAWE}

\section{Bepaling van die betekenis van die woord Charisma}

Die woord Charisma in die Nuwe Testament word in die Afrikaanse vertaling weergegee as ,genadegawe". Dit is ongetwyfeld die beste vertaling daarvan, aangesien dit die werklike betekenis en inhoud daarvan baie duidelik na vore bring.

W. Bauer gee die volgende vertaling: „A gift, freely and graciously given." 1 Gabe."”

Otto Michel vertaal dit met: „Das Geschenkte”, „die

'n Genadegawe is 'n gawe of geskenk wat goedgunstiglik of genadiglik aan iemand geskenk word. Hier is dus geensins sprake dat só 'n gawe deur verdienste verkry kan word nie.

Dit is 'n gawe wat iemand vir 'n korter of langer periode kan ontvang, maar dit bly altyd 'n ,gawe". En hierdie ,gawe", as genadegawe, al is dit aan iemand geskenk, bly altyd verbonde aan die Gewer daarvan. ${ }^{3}$ Daarin lê juis die betekenis van hierdie "gawe". Hier is dus geen sprake daarvan dat die mens kan reken dat hy só 'n gawe kan verwerf, en dat dit voortaan tot sy persoon kan behoort nie. Dit word nooit 'n soort Christelike eienskap of iets dergeliks nie. Dit bly altyd 'n ,gawe" in die hand van die Here - 'n ,gawe" wat God uit genade aan sekere mense skenk. Dit is die konkrete bewys van die genade en goedheid van God. En wanneer daar van goddelike genade sprake is dan is God altyd die Een wat handel terwyl die mens die een is wat ontvang.

In I Korinthiërs $12: 31$ kan dit miskien lyk of die mens self die gawes kan bekom, deurdat Paulus aan die gemeente van

* Verhandeling ingedien ter vervulling van 'n deel van die vereistes vir die B.D. graad aan die Universiteit Pretoria, onder leiding van prof. dr. S.

P. J. J. van Rensburg, November 1967.

1. W. Bauer, A Greek-English Lexicon of the New Testament and Other Early Christian Literature, Cambrdigde-Chicago 1959, bl. 887.

2. Otto Michel, Der Brief an die Römer, Göttingen. Vandenhoek \& Ruprecht 1963, bl. 48.

3. Ds. A. Hiịmans, Geloofsgenezing, Boekencentrus N.V. 'S-Gravenhage 1962 , bl. $8 \dot{2}$. 
Korinthe sê: „Maar beywer julle met die oog op die beste gawes." Dit is wel só dat die gemeente moet streef na die beste gawes, maar hulle kan dit alleen doen deur te bid, dat God dit in die gemeente sal gee. Volgens I Korinthiërs 12:11 word dit dan ook aan God oorgelaat, aan wie Hy dit wil skenk. Die individuele Korinthiërs mag e $n$ kan nie streef om 'n ,genadegawe" te ontvang nie. Dit sou slegs as hoogmoed bestempel word, terwyl I Korinthiērs 12:11 dit in elk geval as onmoontlik verklaar.

Dic hele saak sal nóg duideliker word as die woorde vir „genade" in die Ou Testament en in die Nuwe Testament nagegaan word. In die Nuwe Testament het ons die woord charis wat onder andere die volgende betekenisse het: guns, genade, genadige hulp, toegeneentheid ens. ${ }^{*}$ Die konteks waarin die woord voorkom, sal aandui of die klem op 'n toestand van genade (d.i. om in God se guns te wees) of op 'n daad van genade (d.i. genadige hulp van God) ens. moet val. Uit hierdie betekenisse blyk dit dat die inisiatief altyd van God uitgaan en nie van die mens nie.

Wanneer ons verder let op die ekwivalent van charis in die Ou Testament nl. die woord chēn, dan word die saak nóg duideliker. Die snw. chën is een van die kernbegrippe in die Ou Testament en is afkomstig van die werkwoord hnn wat beteken : genadig wees, erbarm, om neer te buig - van bó na benede; van die meerdere tot die mindere; van Hom wat kan help tot diegene wat hulp nodig het. ${ }^{5}$ Nêrens veronderstel dit 'n teëprestasie van die „mindere" nie!

Ook wat betref die "gawe" wat uit genade aan sekere mense geskenk is, is dit só dat God die outeur daarvan bly. „De genadige gezindheid van God wordt tot een gave Gods in de mens, een begaafdheid zoals deze hem afzonderlijk is geschonken." Die mens kan alleen maar bid dat God uit genade een of ander van hierdie gawes aan hom sal skenk (vgl. Jakobus 1:5). Hierdie gawes is beslis nie iets waarop die mens, as vanselfsprekend, aanspraak kan maak en waarop dan beslag gelê kan word nie, want dit bly inderdaad altyd 'n - genadegawe !

\section{Die gebruik van die woord Charisma in die Nuwe Testament}

Die Woord Charisma kom 27 keer in die Nuwe Testament voor - $20 \mathrm{keer}$ in die enkelvoud en 7 keer in die meervoud.

4. W. Bauer, a.w., bl. 885 .

5. Koehler-Baumgartner, Lexicon in Veteris Testamenti Libros, Leiden 1958 , bl. 314 .

6. Dr. A. F. N. Lekkerkorker, De Brief van Paulus aan de Romeinen II, G. F, Callenbach N.V., Nijkerk 1965, bl. 113. 
Charisma is van huis uit 'n Hellenistiese begrip, wat in die Nuwe Testamentiese literatuur oorwegend deur Paulus gebruik word. In die vier Evangelies en die boek Handelinge kom die woord gladnie voor nie. Dit word slegs in die briewe van die apostel Paulus aangetref en één keer in I Petrus. Hieruit kan ons aflei dat die begrip ,genadegawe" eintlik deur Paulus in die teologiese spraakgebruik na vore gebring is. E. Kăsemann sê onder andere: „Durch Paulus wird das Problem der Geistesgaben grundsätzlich entdeckt."' Paulus het dié begrip in verskillende variasies gebruik, maar in alle gevalle lê daar 'n besondere klem op die genade - karakter van die gawe.

Moontlik was Paulus in sommige gevalle daartoe gedwing om die ,genadegawe" te behandel en te beoordeel aangesien daar verkeerde opvattings in verband daarmee in daardie tyd geheers het. Hy het gepoog om die hele begrip in die regte perspektief te stel, maar terselfdertyd het daar vrae na vore gekom. E. Käsemann stel egter : „Er beantwortete es, indem er den wohl in der Diasporasynagoge gelegentlich, aber unterminologisch gebrauchten Begriff Charisma in die theologische Sprache einführt und damit die herrschende Anschauung von den Geistesgaben $\mathrm{zu}$ verdrängen sucht."

En soos ons reeds daarop gewys het, is Charisma van huis uit 'n Hellenistiese begrip - daar het dus verskeie ander voorstellings in verband met die „genadegawes" geheers, wat vreemd was vir die Christelike geloof, en dit was Paulus se taak om die werklike inhoud daarvan duidelik aan die lig te bring. ${ }^{9}$

Verder is dit opvallend dat Paulus heel dikwels die begrip „genadegawe" gebruik, sonder om presies aan te dui wat hy daarmee bedoel. In somige gevalle kan ons wel aflei wat hy daarmee bedoel, maar dit is nie altyd heeltemal seker nie.

In II Korinthiërs $1: 11$ praat Paulus van 'n ,genadegawe" wat persoonlik aan hom geskenk is. Hy het in baie gevaarlike omstandighede verkeer, maar God het hom daaruit gered; ook in Korinthe moet daar nou vir hierdie ,genadegawe" gedank word. Genadegawe beteken hier dus: uitredding uit doodsgevaar, onverwagte bevryding, moontlikheid van nuwe arbeid, blydskap na die voorafgaande wanhoop. Ook F. J. Pop sê : „Het ligt voor de hand te denken aan de genadegave van de uitred-

7. Die Religion in Geschichte und Gegenwart, Zweiter Band. (Dritte Auflage) 1958, bl. 1275 .

8. Die Relig on in Geschichte und Gegenwart, Zweiter Band, (Dritte Auflage) 1958 , bl. 1275 .

9. Oor die inhoud van die genadegawes later meer. 
ding, die aan Paulus is meegedeeld. Alle heilswerk, alle reddingswerk Gods is genadegave."10

Maar aan die anderkant stem Dr. F. W. Grosheide nie hiermee saam nie. Hy beskou die begrip ,genadegawe" hier as al die genadegawes, wat die Here aan Paulus gegee het vir die vervulling van sy apostoliese amp. ${ }^{11}$

Volgens die algemene opvatting wys hierdie „genadegawe” tog na die verlossing uit die gevaar waarin Paulus hom bevind het, soos F. J. Pop dit ook sien - maar tog sien ons dat daar verskillende sienings oor hierdie bepaalde geval is, waar Paulus praat van die begrip "genadegawe".

In enkele ander gevalle noem Paulus net die woord ,genadegawe" sonder om daarby aan te toon wat hy eintlik daarmee bedoel. Dit is asof hy dit net in die verbygaan meld. Al verklaring wat hiervoor gegee kan word, is dat Paulus veronderstel dat die bepaalde gemeente aan wie hy die woorde rig, presies weet wat hy bedoel met die begrip „genadegawe”.

Só lees ons in I Korinthiërs $1: 7$ byvoorbeeld dat Paulus die gemeente daarop wys dat hulle nie hoef te kla nie omdat hulle in geen enkele ,genadegawe" agterstaan nie. Hier word nie direk gesê wat hierdie "genadegawe" is nie. Dr. F. W. Grosheide pleit daarvoor dat "genadegawe" hier in 'n algemene sin verstaan moet word, terwyl die ,besondere genadegawes"12 vanselfsprekend daaronder val. ${ }^{13}$ Later in sy brief kom Paulus dan wel daarop terug (vgl. I Korinthiërs 12).

Ook F. J. Pop se gedagtegang loop in hierdie rigting met die volgende verklaring: „De apostel denkt hier aan al die geestelijke gaven, die nog vóór de voleinding van het heilswerk Gods aan de gemeente geschonken worden." ${ }^{14}$

Nóg 'n interessante aspek in verband met die begrip ,,genadegawe" wat Paulus na vore bring, lê in die waarskuwing wat hy tot sy medewerker Timotheus rig. In I Timotheus $4: 14$ waarsku hy Timotheus om nie die ,genadegawe" wat in hom is te verwaarloos nie, en in II Timotheus $1: 6$ herinner hy hom daaraan

10. F. J. Pop, De Tweede Brief van Paulus aan de Corinthiërs, Callenbach - Nijkerk 1962, bl. 20.

11. Dr. F. W. Grosheide, De Tweede Brief aan de Kerk te Korinthe, KokKampen 1959, bl. 46-47.

12. Oor die besondere genadegawes later meer.

13. Dr. F. W. Grosheide, De Eerste Brief aan de Kerk te Korinthe, KokKampen 1957, bl. 41 .

14. F. J. Pop, Die Eerste Brief van Paulus aan de Corinthiërs, Callenbach - Nijkerk 1965, bl. 16. 
om die "genadegawe" van God aan te wakker wat in hom is. Hierdeur dui Paulus aan dat só 'n waardevolle gawe wel verwaarloos kan word. Hy doen hier eintlik 'n beroep op Timotheus om baie sorgvuldig met hierdie „genadegawe" om te gaan, as iets baie kosbaars. Dr. William Hendriksen druk dit baie mooi en duidelik uit in sy kommentaar op Timotheus : „He must never grow careless about it or neglect it."15 Uit hierdie woorde kan ons aflei hoe belangrik Paulus hierdie begrip ,genadegawe" beskou het. Dit was nie iets wat aan enigiemand gegee is nie en daarom moes Timotheus nie só ligtelik daarmee omgaan nie.

Ons het hier nou enkele plekke aangedui waar Paulus die begrip ,genadegawe" gebruik, sonder om die ",besondere genadegawes" spesifiek aan te dui. Uit dit alles blyk dit egter dat hierdie begrip ' $n$ baie belangrike plek in die teologie van Paulus ingeneem het en dat hy 'n besondere waarde daaraan geheg het.

\section{Deur wie word die Charismata geskenk}

In I Korinthiërs $12: 4$ stel Pauius dat daar wel 'n verskeidenheid van genadegawes is, maar dit is dieselfde Gees. Nou staan hier nic met soveel woorde dat die Gees sonder meer die "genadegauts" skenk nie. Al wat Paulus eintlik hier doen, is $\mathrm{cm}$ die verskeidenheid van die gawes te stel teenoor die eenheid var. die Gees - hy bekJemtoon die feit dat al dia gawes hulle eenheid vind in die Gees.

Ting lê daar reeds in die woord Charisma self die gedagte. van gawe en met die oog op vers 8 kan met sekerheid gesê word dat die Heilige Gees al die gawes uitdeel an ook die karakter van elke ,gawe" bepaal. Ook Otto Michel bevestig dit deur sy uitspraak: „Paulus verwendet charismata in der Bedeutung von pneumatika"16 (vgl. Romeine 1:11). Al die "genadegawes" is dus geestelike gawes, met ander woorde dit word deur die Gees geskenk.

Ons moet hier egter net duidelik onderskei tussen die gawe van die Heilige Gees en die gawes van die Heilige Gees. Die gawe van die Gees, dorea tou hagiou pneumatos in Handelinge $2: 38 ; 10: 45$ (vgl. Handelinge $8: 20 ; 11: 17$ ) is die Heilige Gees self, wat God as dorea aan sy Kerk geskenk het. Dit is die gawe waarmee die Kerk met die Pinkstergebeure toegerus is om sy roeping te vervul (vgl. Handelinge 1:8). Die genitief tou hagiou pneumatos is hier dus die epeksegetiese genitief. Hiervan moet

15. Dr. William Hendriksen, A commentary on the epistles to Timothy and Titus 1964, bl. 159.

16. Otto Michel, a.w., bl. 48. 
onderskei word, die gawes van die Heilige Gees as die Pinkstergees; ta charismata tou pneumatos hagiou, d.i. die genadegawes, die bekwaamhede waarmee die Heilige Gees die Kerk en gelowiges toerus om hulle roeping te vervul.

Ook F. J. Pop beklemtoon die feit dat dit die Heilige Gees is wat die "genadegawes" skenk deur te verklaar: „Het verschil in genadegaven en de verdeling ervan over diverse gemeenteleden behoeven niemand in verwarring te brengen. Want het is de eene Geest, die op deze wijze met deze heilsgoederen handelt."1:

Dat die „genadegawes" besondere gawes van die Heilige Gees is, word verder bevestig deur dr. William Hendriksen : „It is a precious charisma, that is, a special gift of God's grace bestowed upon him by the Holy Spirit."18

Hierdie ,genadegawes" behoort in 'n besondere sin tot die werk van die Heilige Gees. Dit is só dat alle gelowiges deur die Gees gelei word (vgl. Romeine 8-14) maar hier vind 'n heel Gees gelei word (vgl. Romeine $8: 14$ ) maar die Gees plaas. Hier werk die Gees op 'n heel besondere wyse. Dit gaan hier om werklike heilsweldade wat geskenk word deur die Heilige Gees. Hierdie ,gawes" is besondere ,gawes" en word gekenmerk deur die ,genadekarakter" wat baie sterk na vore tree.

Hier gee God eintlik 'n groot verrassing, 'n besondere kragtige deurwerking van die nuwe lewe ${ }^{19}$ en veral 'n baie sterk moontlikheid tot ontplooiing van aktiwiteit.

Nou kan ons ook eers die rede sien waarom die begrip „genadegawe" nie in die vier Evangelies voorkom nie - want die Heilige Gees is eers uitgestort na die hemelvaart van Jesus Christus (vgl. Johannes $7: 39$ ). Aangesien die "genadegawes" deur die Heilige Gees as Pinkstergees geskenk word, kon só iets nie bekend gewees het, voordat die Heilige Gees eers uitgestort is op die gemeente nie.

In die boek Handelinge kom die woord Charisma ook nie voor nie maar tog het die begrip of verskynsel - "genadegawe" wel voorgekom, al word dit nie spesifiek só aangedui nie. Ons kan hier byvoorbeeld dink aan die genesing van Enéas deur Petrus (vgl. Hand. 9:32 v.v.) - wat as 'n ,genadegawe" van gesondmaking gesien kan word.

17. F. J. Pop, a.w., bl. 270.

18. Dr. William Hendriksen. a.w., bl. 159

19. Oor dié begrip later meer. 
Soos ons ook reeds daarop gewys het, was dit die apostel Paulus wat eintlik eerste hierdie woord Charisma gebruik het en dit verder uitgewerk het. Lukas die skrywer van die boek Handelinge was dus bekend met dié verskynsel maar hy het nie die woord Charisma daarvoor gebruik nie. Dit was eers Paulus gewees wat dié woord uit die Hellenisme oorgeneem het en dit in die Nuwe Testamentiese literatuur ingebring het.

Dr. H. Berkhof sê onder andere dat die verskil by Lukas en Paulus só groot is dat ' $n$ mens geneig is om te glo dat hulle oor verskillende sake spreek. Hy probeer dan hierdie verskil te verklaar deur te sê dat Lukas as historikus spreek; hy wil beskryf hoe die Evangelie sy weg gevind het van Jerusalem na Samaria en na die eindes van die aarde. In verband met sy doelstelling het hy dan beskryf hoe die Heilige Gees op vier verskillende tye 'n deurbraak gemaak het (die eerste op die dag van Pinkster in Jerusalem, die tweede in Samaria, die derde onder die proseliete in Cesarea en die vierde in die heidense wêreld van Efese) terwyl Hy Homself (d.i. die Heilige Gees) geopenbaar het in die "vervulling", die spreek in tale en profesie. ${ }^{20}$ Dit gaan dus vir Lukas hier suiwer net om die gebeurtenis van die koms van die Heilige Gees as eenmalige Pinkstergebeure terwyl die suiwer bo-natuurlike „verskynsels" wat daarmee gepaard gegaan het, nie as "genadegawes" beskou kan word in dieselfde $\sin$ as wat Paulus dit behandel nie.

Die apostel Paulus aan die anderkant lê weer minder klem op die gebeurtenis van die koms van die Heilige Gees; hy lê hom meer toe op die behandeling van die gekome Gees, wat werk deur die Charismata. Dr. H. Berkhof sê dan ook onder andere : "Anders dan Lukas is zijn doel niet het geven van historische informasie, maar van pastorale leiding" en verder: „In die situatie ontwikkelt Paulus wat we kunnen noemen een theologie van de vervulling met de Geest." ${ }^{11}$

Indien 'n mens hierdie verskil tussen Lukas en Paulus aan 'n ontwikkeling wat kon plaasgevind het, wil toeskryf (in die strengste sin van die woord is hier moeilik sprake van 'n ontwikkeling wat kon plaasgevind het), dan kan 'n mens dit alleen doen in die lig nl. dat Lukas die koms van die Heilige Gees beskryf terwyl Paulus hom in sy geskrifte weer besig hou met die Heilige Gees wat alreeds gekom en wat werk deur die Charismata.

20. Dr. H. Berkhof, De leer van de Heilige Geest, Callenbach - Nijkerk (Tweede druk), bl. 96.

21. Dr. H. Berkhof, a.w., bl. 96. 


\section{Aan wie word die Charismata geskenk}

In die meeste gevalle blyk dit dat die ,genadegawes" aan enkele gelowiges in die christelike gemeente gegee is (vgl. I Petrus 4:10). Só besit ook Paulus self genadegawes (vgl. I Korinthiërs $7: 7$ ) asook sy medewerker Timotheus (vgl. I Timotheus $4: 14$; II Timotheus $1: 6$ ).

Slegs in een geval spreek Paulus terloops van die "genadegawes" aan 'n groep persone en in hierdie geval van die "genadegawes" aan die volk Israel (vgl. Romeine $11: 29$ ). Dit bestaan uit die ontfermende genade van God, wat aan Israel 'n besondere plek te midde van die volkere gegee het. God se liefde vir Israel word hier aangedui met die begrip ,genadegawe”. „Israel bleibt das Volk der Wahl und des Segens" sê Paul Althaus in sy kommentaar.": Want God neem sy genadegawes" en sy roeping nie terug nie. God laat Israel as sy volk nie los nie.

Ook Otto Michel sien die uitverkiesing van Israel só as hy sê : „Hier in Römer $11: 29$ denkt er an die geschichtlichen Vorzüge Israels, die in Römer 9:1 aufgezāhlt wurden."23

In al die gevalle blyk dit egter dat die Heilige Gees die ,genadegawes" gee aan wie Hy wil; op die wyse en in die mate waarin Hy dit nodig ag. Vry en soewerein deel $\mathrm{Hy}$ die gawes uit, terwyl daar terselfdertyd 'n groot verskeidenheid in die werk van die Gees is. Dit word duidelik uit die groot aantal „genadegawes" wat daar in die Nuwe Testament genoem word.

\section{Die Charismata is geen permanente besit nie}

Soos ons reeds daarop gewys het, bly „genadegawe" altyd 'n gawe - en al is dit ook aan iemand geskenk bly dit altyd aan die Gewer daarvan verbonde. Die ontvanger beskik nie daaroor, soos oor iets wat sy eie is nie. Daarom kan dit ook enige oomblik teruggeneem word, al doen die Here dit, volgens I Korinthiërs, nie dikwels nie, ter wille van die welsyn van Sy gemeente. Hierdie ,genadegawes" kan verspeel word deur verontagsaming daarvan, deur ongehoorsaamheid, deur selfsug of geestelike selfverheffing. Die Here God kan dit miskien ook terugneem, omdat Hy dit in 'n bepaalde situasie nie meer nodig vind nie. In só 'n geval is dit geen oordeel oor die ontvanger nie - Hy kan dan dankbaar sê dat sy diens vervul is.

22. Paul Althaus, Der Brief an die Römer, Göttingen - Vandenhoek \& Ruprecht 1966, bl. 118.

23. Otto Michel, a.w., bl. 283. 


\section{Die doel waarvoor die Charismata geskenk word}

In Romeine 1:11 dui Paulus baie duidelik die doel aan waarom die "genadegawes" geskenk word en dit is : dat die gelowiges versterk kan word. Dr. A. F. N. Lekkerkerker stel dit baie treffend: "dat alle genadegaven aan één criterium onderworpen zijn: de versterking van de gemeente."24

In die eerste plek sal ans hier moet dink aan die algemene geestelike versterking wat daar van die apostoliese prediking uitgegaan het. Origens dek die woord ,genadegawe" seker ook die veelheid van allerlei besondere geestelike gawes (vgl. bv. I Korinthiërs 12).

Die vroeg Christelike gemeentes het heel dikwels gebuk gegaan onder swaar vervolgings en lyding. Dan was die gevaar van afval van die Christelike geloof baie groot en om hierdie rede is die "genadegawes" aan hulle geskenk nl. om hulle te versterk in hulle stryd en nood - sodat hulle standvastig kan bly ten spyte van al die gevare wat op hulle aanstorm.

Soortgelyk aan die uitsprake oor hierdie Charismata wat genadiglik verleen word aan die vervolgde Christene, wat ter wille van Christus ly, (vgl. Filippense $1: 29$ ), is die uitsprake waarin verhaal word hoe aan die vervolgde Christene onder swaar omstandighede 'n besondere mate van die Heilige Gees gegee word, om hulle te versterk onder lyding en martelaarskap. Ons dink hier aan uitsprake soos Handelinge $4: 8 ; 4: 31 ; 7: 55$; $11: 24 ; 13: 9,52$.

Die ,genadegawes" moes as doel hê, die versterking van die gemeente en dit moes nie gebruik word as iets om ten toon te stel of om mee te spog nie.

Maar dit is nie die enigste doel van die "genadegawe" wat gegee word nie. Ook in I Petrus $4: 10$ word 'n verdere doel aangedui nl. dat die gelowiges mekaar daarmee moet dien. Dit is ongetwyfeld 'n baie belangrike en wesentlike doelstelling vir die gemeente. Dit gaan hier om die welsyn van almal in die gemeente (vgl. I Petrus $4: 11$ ).

In die gemeente behoort daar 'n onderlinge liefde te wees tussen die lede. Wie tot die gemeente van Christus behoort, is met alles wat hy het aan die ander verbonde. Elkeen is aan die ander gebonde tot diens. Diens beteken hier: beskikbaar wees vir die ander; bereid wees om te gee; afgesien van eie belange

24. Dr. A. F. N. Lekkerkerker, De Brief van Paulus aan de Romeinen I, Callenbach - Nijkerk 1962, bl. 40. 
en op die behoeftes van ander let. ${ }^{25}$ Om te dien is 'n groot gebod in die gemeente (vgl. Markus 10:43 en 44). Dit behoort wesentlik tot die nuwe wyse van lewe, wat in Jesus Christus geskenk is, dat die een aan die ander gebonde is en tot diens aan die ander geroep is. Diens is 'n eskatologiese vorm van lewe. ${ }^{26}$

By hierdie ,genadegawes" gaan dit nooit om die „besit” daarvan nie, maar altyd om die "diens" - tot welsyn van almàl. ${ }^{2 i}$ En die moontlikheid om te dien en die noodsaaklikheid van diens is gegee in die feit, dat nie al die lede van die gemeente dieselfde "gawe" van die Heilige Gees ontvang het nie. Die "gcinadegawe" wat elkeen ontvang het, was nie vir elkeen dieselfde nie. Die Gees skenk verskillende gawes. Weer moet ons beklemtoon dat ons met die woord ,genadegawe" nie moet dink aan aangebore begaafdhede nie, maar uitsluitend aan die geestelike gawes, wat saamhang met en voortvlaei uit die heil, wat in Christus geskenk is.

Die veelheid van gawes bewys die rykdom van God. Hy het vir elkeen 'n gawe, wat in die groot geheel nodig is. Hy skenk aan elkeen 'n gawe, wat by hom pas. Juis só bou God die gemeente tot 'n geheel op. Nie ondanks die veelheid van hierdie gawes nie, maar juis deur die verskillende gawes leef die gemeente as 'n eenheid. Want niemand mag die gawe, wat hy toevallig ontvang het, vir homself bewaar en gebruik nie. Elke gawe verplig die een wat dit besit tot diens. En juis die verskillende soorte van gawes maak hierdie diens moontlik, want as almal dieselfde gawe besit het, sou hulle mekaar nie tot enige diens kon wees nie. Hierdie verskil van gawes maak die diens dan ook noodsaaklik.

Die „genadegawes" moet dus altyd dien tot opbou van die geheel. Dit is wel só dat die "genadegawes" aan bepaalde persone in die gemeente geskenk word tot beter toerusting vir hulle eie diens maar dit moet altyd die welsyn van almal ten doel hê. (vgl. I Korinthiërs 12:7). Die ,genadegawes" is gawes aan enkelinge maar hulle is nooit bedoel vir private gebruik nie. ${ }^{28}$ 'n "Genadegawe" is geen persoonlike besit waaroor elkeen hom in afsondering mag verheug nie. 'n „Genadegawe" roep op tot diens, omdat dit by elkeen anders is, en die groot geheel van die gemeente bestaan uit die totaliteit van wat God aan almal saam

25. Dr. M. H. Bolkestein. De Brieven van Petrus en Judas, Callenbach - Niikerk 1963, bl. 162.

26. Dr. M. H. Bolkestein, a.w.. bl. 162.

27. Ds. A. Hijmans, a.w., bl. 78 .

28. Dr. H. Berkhof, a.w., bl. 97. 
gegee het. Hier is dus ook geen sprake om na aanleiding van die "genadegawes" in die gemeente van Christus die gedagte toe te laat van 'n laere en hoëre rang onder die Christene nie. Daar bestaan in die gemeente van Christus geen rangorde nie. Ten spyte van al die besondere gawes of aanleg of moontlikhede is al die gelowiges voor Christus gelyk - almal staan as sondaars voor Hom.

Daarom moet elkeen wat só 'n besondere gawe besit, daarvoor waak dat hy nie bokant homself uitgryp en in hoogmoed homself bokant die ander stel nie. Hy moet die gawe in diens stel van die geheel. Dit is blykbaar ook die rede waarom Paulus dit nodig gevind het om die verskillende gawes op te som. Hy noem dan ook byna by elke "genadegawe" die maatstaf waarvolgens elkeen beoordeel moet word en wat mens daarby as doel moet stel.

Deur mekaar te dien met die verskillende „gawes", word die gemeente terselfdertyd opgebou. Paulus werk hierdie gedagte ook baie goed uit in sy eerste brief aan die Korinthiërs (vgl. I Korinthiërs 12:12 v.v.) waar hy gebruik maak van die beeld van die liggaam en sy ledemate. Die liggaam funksioneer eers korrek wanneer die ledemate 'n groot verskeidenheid vertoon. Só is dit ook die geval met die gemeente as liggaam van Jesus Christus.

Verder ken die gemeente ook geen lede wat "genadegawes" ontvang het, en dan in passiwiteit mag verval nie. Elkeen sal die gawe wat hy ontvang, moet gebruik tot diens van die ander in die gemeente. Alleen só kom die gemeente as gemeente tot volle ontplooiing.

Ons het nou wel genoem dat die ,genadegawes" as doel het die versterking van mekaar onderling en die opbou van die gemeente, maar in die eerste plek gaan alles daarom, dat Christus daarmee gedien moet word.99 Ook prof. Herman Ridderbos sluit hierby aan en stel dat God die "genadegawes" aan die gelowiges skenk ,om daardoor zijn gemeente te bouwen en zijn naam te verheerlijken." ${ }^{30} \mathrm{Al}$ die doelstellings van die verskillende ,genadegawes" word dan as 't ware op een punt saamgetrek en dit is: die diens aan en verheerliking van God.

29. Prof. dr. J. H. Bavinck, Ik geloof in de Heilige Geest, J. N. Voorhoeve - Den Haag, bl. 56.

30. Dr. Herman Ridderbos, Paulus: Ontwerp van zijn Theologie, KokKampen 1966, bl. 493, voetnoot 43. 


\section{Die liefde van God as grond van die Charismata}

Soos ons in die vorige paragraaf daarop gewys het, het die "genadegawes" onder andere as doel: onderlinge diens in die gemeente en diens aan en verheerliking van God. Maar as die liefde ontbreek is dit vanselfsprekend dat daar geen sprake van diens en verheerliking kan wees nie. Ontbreking van die liefde kan alleen daartoe lei dat elkeen hom op sy eie voorregte sal beroem sonder om die ander daarmee te dien. Teen hierdie gevaar waarsku I Petrus 4:8 reeds in 'n mate en Paulus moes uitdruklik daarop ingaan in die geval van die gemeente van Korinthe (vgl. I Korinthiërs 13).

Ook E. Kāsemann beskou die liefde as 'n wesentlike element van die "genadegawes". Hy verklaar dan ook onder andere: „Wo só Uniformitāt, Neid und Uberheblichkeit fallen, ist gegenseitiger Dienst in der Liebe als der inneren (I Kor. 13; Kol. 3 : 14) und dem Christusleib als der āuszeren Einheit der Charismen (I Kor. $12: 12$ v.v.) möglich." 31

In die gemeente is die onderlinge liefde tussen die lede en die liefde tot God dus 'n noodsaaklike voorvereiste, voordat die "genadegawes" tot hulle reg kan kom.

8. Daar is verskillende Charismata in die Nuwe Testament en almal het ook nie dieselfde waarde nie

In I Korinthiërs $12: 4-11$ dui Paulus slegs aan dat daar 'n verskeidenheid van ,genadegawes" is, maar in I Korinthiërs $12: 31$ gaan hy verder deur 'n beroep op die gemeente van Korinthe te doen om hulle te beywer met die oog op die beste gawes.

Met die gebruik van die woord meizona gee Paulus toe dat daar 'n verskil is tussen die "genadegawes". Nou kan dit miskien lyk of Paulus nie die reg het om die gemeente van Korinthe tg berispe, omdat hulle die een "genadegawe" bv. die glossolalie hoër en beter ag as die ander nie. Paulus sê dan self dat hulle hulle moet beywer vir die beste gawes.

Maar nou is dit só dat die verskil wat daar gemaak word, gemaak moet word volgens 'n objektiewe maatstaf, nl. deur watter "genadegawes" die gemeente die beste gedien en opgebou kan word. Die een "genadegawe" kan bv. tot meer nut wees vir die een gemeente as vir 'n ander gemeente. Die ander gemeente het miskien weer 'n ander "genadegawe" nodig vir sy diens en

31. Die Religion in Geschichte und Gegenwart, a.w., bl. 1276. 
taak in die wêreld, wat die eerste gemeente weer nie baie nodig het nie. God deel dan die ,genadegawes" uit volgens wat elke gemeente nodig het. ${ }^{32}$ Baie duidelik stel Paulus dit in Romeine $12: 6:$ „En ons besit genadegawes wat verskil volgens die genade wat aan ons gegee is." God deel die verskillende "gawes" uit en gee aan elkeen ander ,gawes”. „Die gliedhafte Verschiedenheit der einzelnen entsteht durch die verschiedenen Gaben, die Gottes Gnade den einzelnen gab", verklaar Paul Althaus onder andere in sy kommentaar op Romeine ${ }^{33}$

Dat daar wel 'n verskil moet wees, is noodsaaklik want soos ons reeds daarop gewys het, lê die diensbaarheid van die ,genadegawes juis daarin, dat hulle van mekaar verskil. Maar hierdie verskil mag nie deur die mense misbruik en uitgebuit word nie. Die mense mag nie die een "genadegawe” bó die ander stel ter wille van eie eer en eie gewin nie. Niemand mag hierdie "gawes" aanwend om daarmee te skitter en roem te verwerf nie. „Der fleischliche Stolz, der von sich selbst höher denkt als es sich gebührt, is ebenso verwerflich wie die falsche Demut, die ihr Pfund vergrābt," sê Anders Nygren onder andere. ${ }^{34}$ Naas Paulus se aksent dat die "genadegawes" verskil, beklemtoon hy dit in I Korinthiërs 12:4 v.v. dat hulle almal tog deur een en dieselfde Gees gegee word, en in die één Gees hulle eenheid het.

Die „genadegawes" verskil alleen met die doel dat die gemeentelede mekaar onderling tot diens kan wees. Indien die een lid 'n beter "genadegawe" as die ander ontvang het, het hy geensins rede om te dink dat hy beter is as al die ander nie.

Niemand het oorvloedig nie. God het dit só gereël dat die verskillende lede mekaar onderling sal dien, elkeen met sy gawe wat aan hom gegee is en elkeen sal daardeur die groei van die geheel dien. Sodoende sal God terselfdertyd ook verheerlik word. Nie een moet homself bokant die ander verhef nie, want almal is behoeftig. Elkeen dien met sy gawe en op dié wyse wat tot voordeel kan strek, maar vergeet daarby nie dat sy gawe slegs een langs die ander is en dat dit netsó noodsaaklik is.

En al verskil die „genadegawes" onderling en al het hulle nie dieselfde waarde nie, word hulle nogtans in die gemeente saamgevoeg tot een groot geheel, wat alleen dien tot die diens aan en verheerliking van God. Want hulle is deur één én dieselfde Gees gegee.

32. Dr. F. W. Grosheide, a.w., bl. 338.

33. Paul Althaus, a.w., bl. 126.

34. Anders Nygren, Der Römerbrief, Göttingen - Vandenhoeck \& Ruprecht 1965 , bl 300 . 


\section{Die verhouding tussen die Charismata en die ampte}

Wanneer ons die opsommings in I Korinthiërs 12 en in Efesiërs 4:11 v.v. onder die gesigspunt van „genadegawe" en "amp" beskou, dan is slegs een konklusie moontlik en dit is, dat die ,amp" ook self 'n "genadegawe" is. Só noem Paulus bv. as werkinge van die Gees naas die genadegawes van gesondmaking en spreek in tale ook die gewone ampte en dienste in die gemeente soos profete, leraars. ens. (vg. I Korinthiërs $12: 28$ ). In Romeine $12: 3-8 \mathrm{kom}$ die bediening, lering, voorgaan en barmhartigheidsdiens ook voor as ,genadegawes" van die Gees naas die profesie. Prof. dr. J. H. Bavinck sê : „Daarom ben ik zo dank baar dat dergelijke ,doodgewone' en ,huiselijke' dingen (dit is die ampte) door Paulus charismata genoemd worden van de Geest." ${ }^{35}$ Ook prof. Herman Ridderbos het geen twyfel hieroor as hy die volgende definisie van "genadegawe" gee nie : „Charisma is alles wat de Geest gebruiken wil en ten dienste stelt voor de toerusting en opbouw van de gemeente, zowel wat tot lering en vermaning, als ook tot het onderlinge diensbetoon of de doeltreffende besturing en regering van de gemeente kan dienen." 3 s

Dit is beslis foutief om hier ' $n$ onderskeid te wil maak tussen die geestelike en die nie-geestelike dienste in die gemeente tussen die „genadegawes" en die ampte. Ook prof. Herman Ridderbos waarsku teen hierdie misvatting wat in die verlede al dikwels gemaak is, wanneer hy sê : „Naar onze overtuiging is de tegenstelling tussen het charismatische en institutionele in de grond der zaak even vals als tussen charismatische en nietcharismatische diensten in de gemeente. ${ }^{3 i}$ Wie 'n teenstelling tussen die institusionele (die ampte) en die geestelike (die ,genadegawes") wil soek, bevind hulle beslis op 'n dwaalspoor.

Prof. Ridderbos noem ook 'n voorbeeld om sy standpunt te regverdig: „Vooreerst rekent Paulus zijn eigen apostolisch ambt onder de gaven, die Christus aan zijn gemeente heeft geschonken (I Kor. 12:28; Eph. 4:11). Ongetwijfeld is het apostelambt van alle ander ambten en diensten daarin onderscheiden, dat de dragers daarvan onmiddellijk door Christus zijn geroepen en voor de gemeente een heel enige, fundamentele betekenis hebben. Maar niettemin blijkt uit dit ambt, met hoe weinig recht er een tegenstelling is te maken tussen ambt en charisma, tussen instituut en Geest en met welke verkeerde categorieën men werkt als men hier het actuele, concrete, ,Ereignis'-achtige

35. Prof. dr. J. H. Bavinck, a.w., bl. 60.

36. Dr. Herman Ridderbos, a.w., bl. 494.

37. Dr. Herman Ridderbos, a.w., bl. 496. 
als een kenmerk van het charisma tegenover het continuele, regelmatige en institutionele van het ambt zou willen stellen."

Ook Anders Nygren het geen probleem hier wanneer hy stel: „Ohne Weissagung, ohne Amt des Gemeindehelfers, ohne Diakonie, ohne Regieren usw. kann die Kirche, die der Leib Christi ist, nicht bestehen oder wachsen." ${ }^{3}$

Hier noem hy die profesie en die amp van die diakonie as 't ware in een asem, sonder dat 'n mens die indruk kry dat daar onderskeid tussen die twee is.

Ons kan hier tot die konklusie kom dat hier moontlik 'n ontwikkeling kon plaasgevind het. Dit wil voorkom asof die individueel-,,charismatiese" by Paulus aan die begin, sterk op die voorgrond getree het, maar dat die klem geleidelik verskuif het na die institusionele en administratiewe. Die glossolalie het verdwyn terwyl die ouderling- en diakenskap sterker op die voorgrond getree het. ${ }^{40}$ Dit wil egter nie sê dat die glossolalie nooit weer sal voorkom nie.

Uit dit alles blyk dit baie duidelik dat die ampte wel „genadegawes" is en dat dit nie in teenstelling staan met die profesie en die glossolalie ens nie. Die „genadegawes” van profesie en glossolalie is nie iets ",bo-natuurliks" en die ,ampte" iets "natuurliks" of ,alledaags" soos sommige beweer nie. Dit is ook geensins noodwendig dat die ,genadegawes" altyd deur wonderlikheid of buitengewoonheid gekenmerk hoef te word nie.

\section{WEERGAWE VAN DIE VERSKILLENDE CHARISMATA IN DIE NUWE TESTAMENT}

\section{Inleiding}

In die vorige hoofstuk is sekere genadegawes al behandel (vgl. paragrawe 2, 4 en 6) waarop nie weer teruggekom sal word in hierdie hoofstuk nie.

Dit is opvallend dat daar verskillende lyste van ,genadegawes" in die briewe van Paulus voorkom en dat hierdie lyste nogal uiteenloop. In vier gedeeltes gee Paulus 'n soort opsomming van die „genadegawes": Romeine 12:6-8; I Korinthiërs $12: 8-10 ; 12: 28-30$ en Efesiërs $4: 11$. Op enkele ander plekke word afsonderlike genadegawes ook genoem: Romeine $5: 15$

38. Dr. Herman Ridderbos, a.w.. bl. 496-497.

39. Anders Nygren, a.w., bl. 300-301.

40. Ook prof. B. J. Engelbrecht meld onder andere in sy Dogmatiekaantekeninge van 1966: Met die jare het sommige gawes verdwvn. Al wat oorgebly het is die gawes van die predikant, ouderling en diaken, 
en $16 ; 6: 23$; I Korinthiërs $7: 7$. Die vraag ontstaan nou waarom daar só 'n groot verskeidenheid van ,genadegawes" in die Nuwe Testament voorkom. Dr. H. Berkhof gee 'n baie goeie rede hiervoor aan as hy sê dat hulle aard verskillend is, ,al naar gelang de individuele capaciteiten, de historische en plaatselijke situatie en de behoeften van het lichaam van Christus en van de wereld."+1

\section{Dié in Jesus Christus verskene heil fn die ewige lewe as genadegawe}

In Romeine $5: 15$ en $6: 23$ het die woord Charisma besondere teologiese betekenis. In Romeine 5:15 dui Paulus die verband tussen Adam en Jesus Christus aan en beklemtoon terselfdertyd ook die verskil in dié sin dat die "genadegawe" van God in Jesus Christus veel meer is as die misstap van Adam wat die sondeval tot gevolg gehad het. Die genade van God knoop die stryd aan teen die verwoestende werking wat daar van die sonde uitgaan. Hier dui Paulus baie duidelik aan dat die lewe méér is as die dood; die vryspraak méér as die oordeel en die "genadegawe" méér is as die oortreding.

Maar dan moet ,genadegawe" hier verstaan word as die heil wat in Christus aan die mensheid geskenk is. ${ }^{22}$ Otto Michel vat dit baie mooi saam met die woorde : „Die Gnadengabe Jesu besteht in seinem Sühnopfer (Rom. $3: 25$ ) und in der Rechtfertigung des Siinders (Rom. $5: 17$ ). ${ }^{43}$

In Romeine $6: 23$ bou Paulus verder voort op hierdie gedagte en stel die "genadegawe" van God as die ewige lewe in Christus Jesus, onse Here, teenoor die loon van die sonde $\mathrm{nl}$. die dood. Hiermee word te kenne gegee dat die mag van die sonde in Christus verbreek is, maar dat in Hom ook alleen die lewe moontlik is, in diens van die geregtigheid. Hier word die ewige lewe beskryf as 'n ,genadegawe" wat direk aan die werk van Jesus Christus verbonde is.

Wanneer Paulus nou die begrip "genadegawe" in hierdie twee gedeeltes gebruik, doen hy dit met 'n doel en dit is : „um jeden Anspruch des Menschen auszuschlieszen." ${ }^{4}$ Hy het dan beslis ook baie goed gekies deur hierdie begrip veral hier te gebruik, want in die verlossingswerk van Jesus Christus het die mens geen deel gehad nie.

41. Dr. H. Berkhof, a.w., bl. 101.

42. Dr. Herman Ridderbos, Aan de Romeinen, Kok-Kampen 1969, bl. 118

43. Otto Michel, a.w., bl. 141.

44. Otto Michel, a.w., bl. 163. 


\section{Genadegawe van die Profesie}

In drie gedeeltes verwys Paulus na die profesie as ,genadegawe". In Romeine 12:7 en I Korinthiërs $12: 10$ noem hy dit terloops en in I Korinthiërs 14 beklemtoon hy die uitnemendheid van die gawe van die profesie. In hierdie hoofstuk bestee hy besondere aandag daaraan. Hy beskou hierdie ,genadegawe" ook as een van die uitnemendste toerustinge vir die Kerk.

Wat die profesie inhou word omskryf in I Korinthiërs $14: 3$ waar ons lees dat hy, wat profeteer, spreek ,tot die mense woorde van stigting en troos en bemoediging." Ons moet dus onder hierdie gawe verstaan die bekwaamheid om in die gemeente telkens op 'n baie konkrete wyse dinge te kan sê, wat onmiddellike insig gee in die wil en die werk van die Here dinge van opvallende diepte en wysheid wat kan dien tot troos en opbouiing in die geloof. Dit is die ,gawe" om aan die gemernte dinge te sê wat in die verlede, hede en toekoms lê - om die wil van God aan hulle duidelik te maak. ${ }^{45}$ Die wesenlike van die profesie is nie die voorspelling nie, maar soos reeds by die profete in die Ou Testament, die vertolking van die boodskap van God deur die profeet aan sy tydgenote. Die treffende daarby is, dat die spreker voel dat hy tegelyk spreker en luisteraar is, en dat hy dit wat hy aan ander gee, ook gekry het. Hy ontvang dit as 'n geskenk van die Gees.

Veral in die tyd toe daar nog slegs enkele boeke van die Nuwe Testament bestaan het, en die gemeente dag na dag voor allerlei vrae gestel is, was daar 'n groot behoefte aan sulke ,profete" wie se woorde deur ander gekontroleer kon word en waarop hulle hulle dan as reël kon verlaat.

Maar die gevaar het in die vroeëre kerk ook bestaan dat hulle die gesag van die profete onkrities laat geld het, met die gevolg dat hulle nie voldoende onderskeid gemaak het tussen die ware en die valse profesie nie. Teen hierdie misbruik moes Paulus ook waarsku. As iemand geprofeteer het moes dit gekontroleer word (vgl. I Korinthiërs 14:29) en die profesie moes geskied na die maat van die geloof (vgl. Romeine 12:6), met ander woorde dit moes in die gemeente bespreek word en getoets word aan die reël van die algemene of gemeenskaplike geloof (die regula fide).

En verder wys Paulus daarop dat die gemeente immers die gawe van die onderskeiding van die geeste ontvang het, en hulle moet dit gebruik.

45. Prof. B. J. Engelbrecht, Dogmatiek-klasaantekeninge 1966. 


\section{Onderskeiding van die geeste as genadegawe}

In Romeine 12:10 noem Paulus hierdie „genadegawe" naas die genadegawe van die profesie. Hierdie twee "genadegawes" sluit baie nou bymekaar aan, aangesien die onderskeiding van geeste eintlik die "waarborg" is van die ware profesie.

Die moontlikheid het altyd bestaan dat iemand indrukwekkende woorde kon spreek, en self ook kon leef met die gedagte dat die Heilige Gees hom vervul en deur hom spreek, terwyl dit in werklikheid ' $n$ heeltemal ander gees is wat met hom werk. Altyd en oral het die gevaar bestaan dat mense hulle deur valse profesieë kon laat mislei. Daarom het die vroeëre gemeentes altyd behoefte gehad aan persone aan wie die Heilige Gees die gawe van die onderskeiding van die geeste geskenk het.

Verder was dit veral in die eerste eeue van die bestaan van die Christelike kerk ook 'n onontbeerlike gawe, omdat daar gedurig gewaak moes word teen allerlei ketterye wat telkens na vore gekom het. Die jong Kerk het tot op daardie tydstip nog baie min teologie opgelewer, terwyl hulle in aanraking gekom het met die heidense wêreld rondom en met vele en moeilike vrae, met die gevolg dat die gevaar van ontsporing somtyds gedreig het. Gedurig moes daar onderskeid gemaak word tussen die regte en die verkeerde, die ware en die valse, dit wat wel van die Heilige Gees is en dit wat nie van die Heilige Gees is nie. Dit was die taak van dié mense in die gemeente aan wie die Heilige Gees die „genadegawe" van die onderskeiding van die geeste toegesê het.

\section{Die Glossolalie of die spreek in tale as genadegawe}

Die sogenaamde glossolalie of die spreek in tale was 'n wydverbreide godsdienstige verskynsel wat in die ou wêreld voorgekom het."' Maar tog is dit 'n verskynsel wat moeilik is om te verklaar. Of dit beskou moet word as 'n soort „brabbeltaal” of „,stottertaal" kan nie met sekerheid gesê word nie want Paulus deel ons gladnie mee hoe die klanke was nie. Prof. Herman Ribberbos sê dat 'n mens miskien moet dink aan 'n soort ,hemeltaal"." 4 Maar die vraag ontstaan dadelik weer: wat is 'n .,hemeltaal"?

Miskien kan die glossolalie verklaar word as 'n oorweldigende, onuitspreeklike saligheidservaring wat mense laat stotter wanneer hulle die gemeenskap van die Heilige Gees ervaar.

46. Dr. H. Berkhof, a.w., bl. 100.

47. Dr. Herman Ridderbos, a.w., bl. 520. 
Die enigste afleiding wat 'n mens uit die gegewens kan maak, is dat Paulus hier dink aan mense, aan tonge wat spreek deur die Heilige Gees. Die Heilige Gces moes aan bepaalde persone diê ,genadegawe” gegee het, sodat hulle onder Sy leiding kan spreek in 'n taal - wat in elk geval nie die gewone menslike taal was nie - maar in 'n taal wat ook self deur die Gees gevorm is. Dr. F. W. Grosheide sluit ook nou hierby aan met sy volgende uitspraak: „Iedereen spreekt met zijn tong, maar wie het charisma heeft, spreekt met een bijzondere, door den Geest gedreven tong. Zo ontstaat een andere taal dan de gewone, een, die vertolking behoeft. ${ }^{19}$

Ook wil dit voorkom of die glossolalie ook nie die spreek van vreemde bestaande tale (lalein heterais glóssais - Handelinge 2:4; I Korinthiërs 12:10), kan wees nie, want om 'n vreemde taal te kan uitlê (vgl. I Korinthiërs 14:5 en 13) is geen besondere "genadegawe" nodig nie. Vreemde tale word tog met die gewone menslike tong gespreek en kan aangeleer word. ${ }^{49}$ Die glossolalie kan dus ook nie beskou word as een van die tale van die vreemde omliggende volke nie.

Gevolglik moet die Charisma van die glossolalie ook onderskei word van die wonder van die spreek in ander tale op die Pinksterdag $-\mathrm{lg}$. gebeurtenis moet gesien word as 'n eenmalige openbaringsteken wat wil aandui dat die Heilige Gees sommige persone bekwaam gemaak het om getuies van Jesus Christus te wees onder al die volkere. Dit het hier gegaan om die spreek in tale, d.i. tale wat in daardie tyd bekend was (vgl. Handelinge $2: 6-12$ ), terwyl die glossolalie blykbaar nie een van die bekende tale van daardie tyd was nie. ${ }^{50}$

Verder is dit opvallend dat hierdie ,genadegawe" slegs in die eerste brief aan die Korinthiërs voorkom. Dit impliseer geensins dat hierdie verskynsel gladnie in die ander gemeentes von:gekom het nie. Ons kan hieruit egter tot die konklusie kom dat die verskynsel van die glossolalie wat met ekstase gepaard gegaan het deur die gemeente van Korinthe as die wonderlikste en beste gawe beskou is. Dit het by hulle besonder op die voorgrond gestaan - in só 'n mate dat hulle die betekenis dasrvan vir die gemeente oorskat het.

Waarom hulle hierdie "genadegawe" só hoog gaskat het, is nie heeltemal duidelik nie. Prof. dr. J. H. Bavinck probeer dit só

48. Dr. F. W. Grosheide, a.w., bl. 338.

49. Nie as argument nie, maar slegs as opmerking kan gesê word, dat die spreek van vreemde tale in die gemeente weinig sin sou hê.

50. F. F. Bruce, The Acts of the Apostles, Wm. B. Eerdmans Publishing Company, Grand Rapids, Michigan, 1960 (Second Edition), bl. 82. 
verklaar: „Misschien kwam deze neiging wel een klein beetjie voort uit een soort minderwaardigheidsgevoel ten opzichte van de haar omringende Griekse cultuurwereld met haar schitterende wijsgerige scholen, haar mysterieuze religieuze stromingen, haar behoefte aan extase"."1 Hierdie argument berus ook maar net op gissings.

Een ding was vir Paulus baie duidelik en dit was dat die oorskatting van die glossolalie gevare vir die gemeentelike lewe ingehou het. Hyself het positief teenoor hierdie verskynsel gestaan - hy het daarin die werking van die Gees erken, maar hy moes waarsku teen die oordrewe wyse waarop die gemeente van Korinthe hulle daarop toegelê het. Die glossolalie het die godsdiensoefeninge in Korinthe begin oorheers, en die goeie orde in die eredienste is daarmee versteur. ${ }^{52}$

Paulus wou hierdie misbruik en oorskatting van die ekstatiese glossolalie in die gemeente van Korinthe aan bande lô pn daarom gee hy enkele aanwysings:

In die eerste plek wys hy hulle daarop dat die Heilige Gees die „genadegawes" in die gemeente gee met die oog op wat nuttig is en tot stigting van die gemeente kan dien (vgl. I Korinthiërs 14:4), maar die gemeente verstaan dit nie, want deur die Gees spreek hy verborgenhede. Die gemeente word daardeur nie gestig nie, tensy die tongetaal ook uitgelê word (vgl. I Korinthiërs 14:5 en 13). ${ }^{53}$

Soos ons reeds daarop gewys het moet die gemeentelede gedurig , terwyl hulle strewe na die „genadegawes”, probeer om uit te munt tot stigting. Hiervolgens stel Paulus die gawe van die profesie, $\left.{ }^{, 4}\right)$ d.i. die gawe om die goddelike openbaring te verkondig en uit te lê, hoër as die gawe van die glossolalie, want deur die profesie word die gemeente gestig en opgebou (vgl. I Korinthiërs 14:3). Paulus wat self daarop aanspraak maak dat hy hierdie gawe besit - selfs in 'n meerdere mate as almal in Korinthe (vgl. I Korinthiërs 14:18) - verkies eerder om vyf woorde met sy verstand in die gemeente te spreek, om ook ander te onderrig, as tienduisend woorde in glossolalie (vgl. I Korinthiërs 14:19).

Dit is dus baie duidelik dat „die uitleg van tale" 'n afsonderlike ,genadegawe" naas die glossolalie is (vgl. I Korinthiërs

51. Prof. dr. J. H. Bavinck, a.w., bl. 64 .

52. Dr. A. M. Bouwer, Paulus de Apostel II - De Mensch en zijn tijd, N.V.G.J.A. Ruys' uijtg.-mij-Zutphen 1934, bl. 258.

53. Dr. A. M. Bouwer, a.w, bl. 238.

54. Vgl. bo, paragraaf 2 . 
12:10). Hierdie uitlegger hoef nie noodwendig iemand anders te wees nie - dit kan dieselfde persoon wees wat die tongetaal spreek (vgl. I Korinthiërs 14:5). Somtyds kan dit wel iemand anders wees (vgl. I Korinthiërs 14:28). Wie in elk geval die gawe van die glossolalie besit, moet van God bid dat hy ook die gawe van die uitleg daarvan mag ontvang (vgl. I Korinthiërs 14:13). Dan eers kan sy gawe vrugbaar word vir ander.

Ook prof. Herman Ridderbos stel: „Het is dit gebrek aan communicatie, dat Paulus als het grote bezwaar tegen de glossolalie inbrengt en waardoor hij de waarde ervan lager aanslaat dan bijv. die van de profetie, tensij het gesprokene word uitgelegd en de gemeente er door gebouwd word. Van de niet uitgelegde glossolalie is echter in dit opzicht niets te verwachten. De onkundige toehoorder kan er geen „,amen" op zeggen”. ${ }^{55}$

In die tweede plek gee Paulus 'n maatstaf waarvolgens die glossolalie beoordeel kan word. Die glossolalie kom as buitengewone ekstatiese verskynsel soseer ooreen met die ekstatiese verskynsels van die heidendom, ${ }^{50}$ dat Paulus 'n kriterqum nodig ag waarvolgens die Korinthiërs kan beoordeel wanneer die glossolalie werking van Gods Gees is, en wanneer nie. Niemand sal, terwyl hy in die Gees van God spreek, Jesus 'n „vervloeking” noem nie, maar sal die belydenis uitspreek: "Jesus is die Here" (vgl. I Korinthiërs 12:3) of "Jesus Christus is die Here" (vgl. Filippense 2:11). ${ }^{57}$

Behalwe die profesie is die glossolalie een van die ,genadegawes" waarby Paulus die langste stilstaan. Dit is opvallend dat hy dit nie sonder meer veroordeel nie. Hy is ten volle daarvan bewus dat dit 'n ,genadegawe" van die Heilige Gees is en daarom behandel hy dit met groot versigtigheid, ten spyte van die gevare wat dit inhou vir die gemeente van Korinthe.

\section{Die genadegawe van die Bediening}

Wanneer hier in Romeine 12:7 van bediening as ,genadegawe" gepraat word, dan word hier waarskynlik nie gedink aan die amp van die „diakonaat" nie. Hier word veral gewys op die algemene dienste of vorme van bystand in die gemeente (vgl Romeine 16:1; I Korinthiërs 12:5; 16:15). Die Heilige Gees het aan sommige mense hierdie "genadegawe" gegee om die naaste goed en vaardig in sy nood te begryp en te help. Dit gaan dus

55. Dr. Herman Ridderbos, Paulus, bl. 521.

56. Vgl. voetnoot 45 .

57. Prof. dr. S. P. J. J. van Rensburg, Teologie-aantekeninge oor die Heilige Gees 1966, bl. 189 . 
veral hier om die versorging van die armes, die behoeftiges, die siekes en die swakkes in die gemeente.

\section{Die genadegawe van die Lering}

Onder lering (Romeine 12:7; I Korinthiërs 12:29) word waarskynlik gedink aan die vermoë om vanuit die Skrif op deeglike en begryplike wyse onderrig te gee aan ander. Die leraars (didaskaloi) is mense wat die bekwaamheid ontvang het om ander in die christelike oorlewering en voorskrifte te onderrig (vgl. I Korinthiërs 4:17; II Timotheus 2:2). Hulle werksaamheid het dus gestrek oor die hele inhoud van die Evangelie - daarom het dit baie nou saamgehang met die verkondiging.

Die waarde van hierdie leraars van die Kerk is nog nooit genoeg na waarde geskat nie. Dit was hulle, eerder as die evangeliste en predikers, wat die Evangeliese tradisie oorgelewer het, en 'n vaste vorm daaraan gegee het. Dit was hulle wat die pasbekeerdes onderrig het in die nuwe geloof en in die christelike lewenswyse, en sodoende die geloof in die Kerk opgebou het. Spore van hulle kategetiese werk vind ons bv. in Hebreërs 6, in I Petrus en Jakobus, asook in die vorm van die Mattheusevangelie, wat miskien biskryf kan word as die oudste christelike kategismus. ${ }^{38}$

Ons kan aanneem dat hierdie leraars in die tyd, toe die mondelinge tradisie nog die vernaamste bron van kennis van die christelike geloof was 'n belangrike diens gelewer het. Ook het hulle die taak gehad om vaste oorleweringsstof oor te dra, waarby met name ook die tradisie aangaande die Ou Testament 'n groot rol gespeel het.

Of hierdie „leraars" wel 'n amp beklee het, is moeilik om te bepaal. Herman Ridderbos sê: „Van een bepaalde leraarsambt, d.w.z. het in en door de gemeente tot leraar aangesteld worden, lezen wij niet". .9 Tog kon die moontlikheid bestaan het dat persone wat wel hierdie bepaalde "genadegawe" besit het, deur die gemeente geroep is tot die amp van leraar (vgl. I Timotheus 5:17) - hier bestaan geen rede waarom dit nie so kan wees nie.

Aan die anderkant was daar seker beslis ook leraars in die gemeente wat geen amp beklee het nie, want nêrens kry ons 'n aanduiding dat die ,genadegawe" van die lering noodwendig gepaard móét gaan met een of ander amp in die Kerk nie. Volgens

58. Frederick C. Grant, An Introduction to the New Testament Thought, Abingdon Press. New York - Nashville. bl. 298 v.

59. Herman Ridderbos, Paulus, a.w.,, bl. 506. 
Otto Michel lê Paulus hier ook nie sóseer nadruk op die gáwe of op die ,amp" of „rang" van die persoon wat die ,genadegawe" besit nie. Hy verklaar: „Es fāllt auf, dasz Paulus durch die Partizipien ho didaskón und ho parakalón ${ }^{60}$ die Tātigkeiten und den Vollzug der Charismen betont, nicht só sehr die Begabung oder die Würde des Charismatikers. ${ }^{61}$ Die klem val dan hier méér op die uitvoering en werksaamheid van die ,genadegawes".

Verder geld ook hier wat reeds van die vorige ,genadegawe" gesê is. Hierdie "gawe" moet nie misbruik word deur eie eer daardeur te probeer soek nie.

\section{Die genadegawe van die Vermaning}

Die "gawe" van die lering is besonder nou verwant met dié van die vermaning (Romeine 12:8). Laasgenoemde sien meer op die herderlike, vermanende en vertroostende woord aan ander in die gemeente. Dit sluit ook baie nou aan by die profetiese werksaamheid (vgl. I Korinthiërs 14:3 en 31).

Die ,genadegawe" van die vermaning is ook baie prakties - dit gryp direk in die lewe van mense en is daarom baie gevaarliker en dit vra meer moed. Om dit goed en waardig te kan doen, is 'n groot "gawe" van die Heilige Gees - 'n "gawe" waarvoor 'n mens van harte dankbaar moet wees en wat deur die gemeente ook hoog op prys gestel maet word.

\section{Die genadegawe van die Uitdeling (Romeine $12: 8$ )}

Daar is mense in die gemeente wat aardse besittings of moontlikhede besit. Wanneer hulle dan ook die genade besit om dit nie gretig vir eie genot te benut nie, maar dit veral sien as 'n mooi kans om andere daarmee te dien dan is dit 'n groot "genadegawe" (vgl. Efesiërs 4:28). Maar dan moet dit gedoen word in eenvaud, sonder enige bybedoeling en in onbaatsugtigheid. Hier moet geen ander oorweging 'n rol speel, behalwe om diê wat in nood is uit te help nie.

\section{Voorgaan as Genadegawe (Romeine $12: 8$ )}

Wat die voorgaan aanbetref bestaan daar tweërlei moontlikhede: In die eerste plek kan dit beteken, dat daar aangewese persone in die gemeente is wat leiding kan gee (vgl. I Thessalonicense 5:12; I Timotheus 5:17). Hulle besit die bekwaamheid om in die gemeente voor te gaan wanneer dit ookal nodig mag

60. Vgl. paragraaf 7 .

61. Otto Michel, a.w., bl. 299. 
wees. Veral in allerlei situasies, ondernemings en vergaderings het hierdie mense die "gawe" om alles dadelik op te som, dit saam te vat en te sien waar dit presies op aankom.

In die tweede plek kan dit die betekenis hê, om jou oor iemand te bekommer of om vir iemand te sorg. In hierdie verband kan proistamenos 'n persoon aandui wat as beskermheer intree vir die weerloses, bv, weduwees en weses, slawe, vreemdes, ens.

Die eerste betekenis lyk in hierdie bepaalde geval die mees waarskynlikste, ${ }^{62}$ dog die tweede het 'n sekere voorrang. ${ }^{63}$

\section{Die genadegawe om barmhartigheid te bewys (Romeine $12: 8$ )}

Wat die "genadegawe" van die barmhartigheid betref is dit duidelik dat dit baie naby aan die "genadegawes" van die bediening en die uitdeling lê. Dr. A. F. N. Lekkerkerker stel voor dat 'n mens hier moet dink aan die versorging van die wat besondere hulp nodig het soos die siekes, die weduwees en wese. $^{64}$ En dit moet altyd geskied met blymoedigheid met ander woorde, dit moet gedoen word nie asof dit eintlik te veel moeite is nie, maar in volle bereidheid.

\section{1. 'n Woord van Wysheid en 'n woord van Kennis (I Korin- thiërs $12:$ )}

Sowel die wysheid as die kennis het in die gemeente van Korinthe 'n groot rol gespeel. Uiteraard is daar verwantskap tussen die twee, maar dit is opvallend hoe die menings oor die ooreenkoms en die verskil tussen die twee in die verskillende kommentare uiteen loop. Sommige sê dat die wysheid verband hou met dit wat ons dogmatiek noem, en kennis met die etiek. Ander beskou die kennis weer as die resultaat van die ondersoek van die wyses. Oak prof. dr. J. H. Bavinck sien die saak só wanneer hy sê: „Wijsheid is in het algemeen een aangeboren gave, kennis is meest het product van studie en nadenken. ${ }^{65}$

62. Dr. Herman Ridderbos, Aan de Romeinen, bl. 280.

63. Otto Michel, a.w., bl. 300 , voetnoot 1 .

64. Dr. A. F. N. Lekkerkerker, a.w., bl. 116.

65. Prof. dr. J. H. Bavinck, a,w., bl. 62. 
Dit bly egter moeilik om tussen "die woord van wysheid" en „die woord van kennis te onderskei.66 Op grond van hierdie teks en die konteks waarin dit gebruik word in Paulus se briewe is dit nouliks moontlik om vir ons 'n voorstelling te maak wat Paulus eintlik hiermee bedoel. Wat wel duidelik is, is dat hierdie twee gawes nie in een en dieselfde persoon saam aangetref hoef te word nie. En verder moet dit as ,gawe" van die Gees seënryk ten behoewe van die gemeente aangewend word.

\section{Die Geloof as genadegawe (I Korinthiërs 12:9 en}

Fillippense 1:29).

Volgens Efesiërs 2:8 is geloof 'n gawe van God - dit is die Heilige Gees wat hierdie geloof in ons harte werk.

Maar as Paulus in I Korinthiërs 12:9 van geloof as 'n "gawe" van die Heilige Gees praat, dan wil dit voorkom asof hy hier nie bedoel, die geloof wat by alle gelowiges in die gemeente aan getref word nie. Ook dr. F. W. Grosheide huldig hierdie mening: „Maar omdat er heteró staat, waaruit blijkt, dat de hier bedoelde pistis niet aan allen wordt gegeven, kan men toch niet aan het zaligmakend geloof zonder meer denken. ${ }^{6}$;

Maar watter geloof het Paulus dan in die oog gehad? Die meeste kommentare wil hê dat ons moet dink aan die geloof waardeur die wonders tot stand gekom het, en dan word veral verwys na I Korinthiërs 13:2 om hierdie opvatting te bevestig. Die Heilige Gees skenk aan sommige persone hierdie geloof wat hulle dan instaat stel om wonders te kan verrig. Want ,in de gemeenschap met die Geest wandelen we altijd op de rand van het wonder. ${ }^{68}$ Dr. F. W. Grosheide voeg verder by dat: „De woorden, die er om heen staan, wijzen ons naar een geloof, dat bijzondere, zichtbare resultaten heeft". ${ }^{69}$ Dit is dus 'n geloof wat uitermate dinamiese en aktiewe optrede ten gevolg het. Hierdie verklaring lyk aaneemlik maar dit sal eintlik beter wees om die baie bruikbare uitdrukking van F. J. Pop hier te gebruik: „Niemand zal voor deze opvatting zijn hand in het vuur durven steken, maar wellicht is zij de overweging waard".;o

66. Dr. Herman Ridderbos, Paulus, bl. 500.

67. Dr. F. W. Grosheide, De Eerste Brief aan de Kerk te Korinthe, bl. 325, voetnoot 25.

68. Prof. dr. J. H. Bavinck, a.w., bl. 62.

69. Dr. F. W. 'Grosheide, a.w,, bl. 325.

70. F. J. Pop, De Eerste Brief van Paulus aan de Corinthiërs, bl. 275. 


\section{Werkinge van kragte (I Korinthiërs 12:10 en 28) :}

Netsoos sommige ander "genadegawes" is dit moeilik om te bepaal wat Paulus presies bedoel wanneer hy praat van „werkinge van kragte". Dit moet beslis onderskei word van die genade van die gesondmaking omdat dit afsonderlik vermeld word.

Hierdie „kragte" word aan sekere mense geskenk maar dit is terselfdertyd ook kragte wat werk, dit wil sê dat by sulke mense kom daar werkinge na vore wat 'n mens moet toeskryf aan buitengewone kragte wat aan hulle deur die Heilige Gees geskenk is. Hierdie kragte is openbarings van God se krag as dinamiese tekens van $\mathrm{Sy}$ genade aan die gemeente deur enkele lede van die gemeente aan wie Hy hierdie werkinge van kragte skenk. Dit is omtrent al wat van hierdie hele begrip gesê kan word. Al wat verder gesê word, berus slegs op bespiegelings en niks is seker nie.

Sommige kommentatore stel voor dat 'n mens hier moet dink aan die kragte waarmee demone uitgedryf is. Ander wil weer hê dat 'n mens hierdie kragte eintlik moet sien as dié kragte waardeur die wonders verrig is. 'n Verdere voorstel is dié nl. dat hierdie kragte op die verduur van buitengewone inspanning, soos ons dit sien in die lewe van Paulus en sy metgeselle kan wys.

Die inhoud van hierdie hele gedagte bly egter vir ons in die duister.

\section{Die genadegawe van Gesondmaking}

(I Korinthiërs 12:9, 28 en 30):

Wanneer Paulus praat van die genadegawe van gesondmaking moet dit nie verwar word met ,geloofsgenesing” nie. Daar is wel 'n verband tussen die twee maar ons moet die twee vanmekaar onderskei.

In die woord ,,geloofsgenesing” spreek die gemeente van Christus sy geloof uit $\mathrm{nl}$. dat Jesus Christus die groot Geneesheer is, wat op baie maniere siekes genees en genees het; en dat geloof en gebed andersyds daarin 'n belangrike plek ontvang. Maar dit gaan hierby om die gemeente in sy geheel; in prinsipe is niemand hier uitgesluit nie. Dit gaan hier veral om die lewende, handelende Heer, wat in Sy gemeente, en ook wel daarbute genesings doen.

Maar by die genadegawe van gesondmaking moet ons dink aan 'n besondere gawe wat, al na genoodsaak van plek, tyd en 
omstandighede aan bepaalde mense in die gemeente geskenk is deur die Heilige Gees, hetsy tydelik of blywend.

Wanneer ons nou hierdie begrip van nader beskou, word dit ook duidelik dat ons nie net by I Korinthiërs 12 verse 9, 28 en 30 kan stilstaan nie. Want dit wil voorkom asof Paulus veronderstel dat die gemeente van Korinthe baie goed weet wat hy met hierdie gawe van gesondmaking bedoel. Hy dui dit nie duidelik aan nie; hy omskryf dit nie; hy herhaal eenvoudig die stereotiepe uitdrukking: ,genadegawe van gesondmaking”. Dit is blykbaar vir sy lesers voldoende.

Hierdie lesers ken blykbaar die wonderlike genesings, soos dit bv. in die Handelinge beskryf word (Handelinge 19:11, 12). Miskien was sommige van hulle persoonlike getuies gewees van sulke wondergenesings. En hulle het immers die Evangelie, waarin aan hulle verkondig was hoe die Here Jesus Christus tydens Sy aardse werksaamheid allerlei genesings gedoen, geken. Sulke genesings was dus vir hulle nie iets vreemds nie. Ons kan dus hier die vier Evangelies en die boek Handelinge nie buite rekening laat nie; ons moet juis hier begin.

Hierdie en ander wonders kan gesien word as die voortsetting van die wonderwerke van Jesus Christus, wat op aarde self draer van die Heilige Gees was, en deur die krag van die Heilige Gees wonders van genesinge verrig het. (vg. Mattheus 112:28).

Verskillende woorde word in die Nuwe Testament gebruik vir gesondmaking. In die eerste plek, égeirein wat beteken om op te rig (vgl. Jakobus 5:15); om weer aangesterk te wees.

In die tweede plek is daar hugiés wat gewoonlik by die genesing van geheel of gedeeltelik verlamdes gebruik word, vgl. Mattheus 12:13; 15:31; Handelinge 4:10). Iemand wat weer hugiés geword het, het weer bewegingsvryheid; hy kan iets tot stand bring.

Vervolgens tref ons die werkwoord sózein aan wat beteken om iemand uit 'n gevaar te red, veral uit doodsgevaar (vgl. Mattheus 14:30). Dit kan ook gebruik word, al het die dood reeds ingetree (vgl. Lukas 8:50). Andersyds word juis by sózein die verband tussen sonde, siekte en dood maar ook tussen vergewing, genesing en lewe sigbaar (vgl. Mattheus 9:22; Markus 5:34; Lukas 18:42).

Veral die twee werkwoorde therapeúein en iasthai kom heel dikwels voor. Therapeuein kom sowel in die aktief as in die 
passief voor. Let 'n mens op die passiewe vorm, dan sien 'n mens dat die subjek slegs selde in die enkelvoud staan. ${ }^{i 1}$ Die nadruk lê dan ook meer op Hom wat die genesing verrig, as op die pasiënt. By therapeúein word die feit dus gekonstateer dat Jesus Christus die Groot Geneesheer is.

By iasthai staan die behandeling van die bepaalde siektegeval weer op die voorgrond; van geval tot geval help die Heiland (vgl. Lukas 6:19; 9:11; Handelinge 10:30). Van die werkwoord jasthai is weer die selfstandige naamwoorde iasis en iama afgelei. Inderdaad beteken iasis die handeling van die genesing (vgl. Lukas 13:32; Handelinge 4:22 en 30). Wat iama betref, dui dit in die klassieke Grieks ook die geneesmiddel aan, maar in die Nuwe Testament het sy betekenis verskuif in die rigting van iasis, sodat dit selfs sinoniem daarmee geword het. Charismata iamatón beteken dus dat 'n pasiënt genees is; as resultaat van die behandeling tree die feit van die genesing in.

Uit die woordgebruik volg dus dat by iamata in I Korinthiërs $12: 9,28$ en 30 gedink moet word aan 'n skielike herstel van bepaalde siekes, dus gevalle waarin genesinge as Charismata geskenk is, en wel in verband met die verrassende mag van Christus, die Geneesheer.

Jesus -Christus het verskeie persone genees en hierdie wondergenesings van Hom is ' $n$ aankondiging van die aanbrekende dag van die Here. Dit is tekens van sy Messiasskap; dit is tekens van die voleinding en vervulling van die beloftes wat God in die Ou Testament deur die profete (vgl. Jesaja 35:5 en 6) gegee het - beloftes wat in die komende eeu, in die nuwe bedeling deur die Messias vervul sal word wanneer Hy kom. En as Jesus die blindes laat sien, die dowes laat hoor, die lammes laat loop en die stommes laat praat, dan is dit die vervulling van hierdie beloftes; dan is dit tekens dat die heilstyd aangebreek het, dat die Messias gekom het en dat in Hom die koninkryk van God aangebreek het. Dan is Jesus as die Messias reeds besig om te triomfeer oor alle magte en vyande - die magte van die duisternis en die sonde en die siekte (vgl. Mattheus 8:17).

En hierdie genadegawe van gesondmaking waarvan Paulus hier praat, moet gesien word as 'n openbaring, nl. dat Jesus Christus voortgaan met sy helende werk, maar nou deur die

71. Vgl. Mattheus 17:18, en dan nog gewoonlik in die sin van die ,geneesde pasiënt" (part. perf.); Johannes 5:10; Handelinge 4:14; Lukas $8: 2$ en 43. 
lede van sy liggaam." Daarom kan hierdie genadegawes van gesondmaking, as genadegawe in die gemeente dus allsen verstaan word vanuit die verlossende genade van Jesus Christus, wat die samehang van sonde en siekte deurbreek het. (vgl. Handdeling $3: 12,16 ; 4: 10$ ).

Er verder sê E. Käsemann dat die „genadegawəs" gawes en kragte van die nuwe bedeling is. ${ }^{33}$ Ook die uitstorting van die Heilige Gees was vir die oudste gemeente die teken dat die eindtyd aangebreek het; (vgl. Handelinge 2:17; Joël 2:28 v.v.) en die genadegawes is juis deur die Heilige Gees aan die gemeente geskenk.

En verder het die Heilige Gees ook aan die gemeente van Korinthe die genadegawe van die gesondmaking geskenk sodat die kragte van die nuwe Ryk ook daar tot ontplooiing sou kan kom. Aan enkele gemeentelede is hierdie besondere gawe geskenk om genesingswonders te verrig.

Opmerklik hier is die meervoud charismata iamatón wat gebruik word. Baie het dit toegeskryf aan die feit dat daar allerande siektes was en dat die een 'n gawe besit het vir die een siekte, en 'n ander vir 'n ander siekte. Oor dr. F. W. Grosheide sien die saak só as hy sê: „Elke ziekte onderstelt een eigen charisma". ${ }^{-4}$ Dit beteken natuurlik ook dat aan één gemeentelid gawes geskenk is om 'n verskeidenheid van siektes te bestry.

Verder moet daarteen gewaak word dat nie te veel klem op die siekte as sodanig gelê word nie. Dit gaan hier nie om die mens wat gesond word nie want hy word per slot van sake weer siek en sterf. As iemand gesond word is dit nie t.w.v. homself nie, maar t.w.v. die wonder. Dit is 'n teken dat God die bose magte oorwin; die bose magte van die duiwel, die sonde en die gevolg van die sonde nl. die siekte. Gesondmaking is in die ware sin van die woord, daadwerklike verkondiging dat Jesus Christus die Here en Messias is.

\section{Onthouding om nie te trou nie as genadegawe :}

Wanneer Paulus in I Korinthiërs 7:7 sê dat hy wens dat alle mense soos hy was, dan veronderstel dit dat die gemeente te Korinthe baie goed geweet het, hoe hy was. Hulle het geweet dat Paulus ongetroud was, maar hy maak nou aan hulle bekend dat hy geen behoefte het om te trou nie deurdat 'n genadegawe

32. F. J. Pop, a.w., bl. 294.

73. Die Religion in Geschichte und Gegenwart II, bl. 1275.

74. Dr. F. W. Grosheide, a.w., bl. 276. 
aan hom geskenk is nl. die genadegawe van die onthouding. Hy hoef as gevolg van hierdie gawe nie bevrees te wees dat hy in hoerery sal verval nie. Hy vind die toestand waarin hy verkeer ' $n$ besonder aantreklike toestand, want innerlik en uiterlik is hy op seksuele gebied vry van alle komplikasies en probleme. Daardeur kon hy hom geheel en onvoorwaardelik aan die diens van God wy. Hy hoef hom nie te bekommer oor die versorging van 'n gesin nie en verder hoef hy nie gedurig te waak teen die verleidings van Satan op hierdie gebied nie. Hierdie toestand was vir Paulus ideaal.

Die rede waarom Paulus hierdie ongehude toestand verkies het, word gevind in die ,aanstaande nood" waarvan hy in I Korinthiërs 7:26 praat. Hier word bedoel, die nood waarin die gelowiges in 'n vyandige wêreld verkeer, waarmee Paulus alreeds kennis gemaak het en nóg sou maak (vgl. II Korinthiërs 6:4; 12:10; I Thessalonicense 7:29); die gedaante van hierdie wêreld is besig om verby te gaan (vgl. I Korinthiërs 7:31). Die laaste dae sal weldra aanbreek en dit sal gepaard gaan met groot verdrukking (vgl. Lukas 21:23). Daar moet nie veel waarde geheg word aan die genot van hierdie wêreld nie, al bestaan die lewe vir sommige juis dáárin - van nou af moet ook die wat vroue het, wees asof hulle nie het nie (vgl. I Korinthiërs 7:29b).

En juis vanweë hierdie nood is Paulus bevrees dat die wat getroud is méér verdrukking sal hê vir die vlees (vgl. I Korinthiërs $7: 28$ ) as dié wat ongetroud iis - en juis van al hierdie sorge wil hy hulle spaar. Dit hou tegelyk die religieuse motief in dat diegene wat getroud is meer waarde heg aan die teenswoordige lewe, dat hulle aandag verdeel is - dat hulle meer het aan hulle lewensmaat en die aardse sake as aan die saak van die Here. En terwyl die laaste dag spoedig sal aanbreek het die aardse dinge nie veel waarde meer nie. Dit is dan beter om ongetroud te bly en jou hele lewe te stel in diens van die Here.

Hier is egter geen sprake van 'n soort askese met die bedoeling dat ' $n$ mens ' $n$ hoër trap van volmaaktheid of heiligheid sal bereik as ' $n$ mens nie trou nie. Soos reeds daarop gewys is die motivering suiwer religieus - eskatologies : as gevolg van die aanstaande wederkoms van Jesus Christus is dit beter om ongetroud te bly.

Ook is hier geen sprake daarvan dat Paulus op asketiesdualistiese gronde die geslagsgemeenskap self sondig geag het of die huwelik op grond van asketies-dualistiese motiewe veroordeel het nie. Paulus het die huwelik waardeer as 'n instelling 
van God wat beskerm word deur 'n uitdruklike gebod van Jesus Christus (vgl. I Korinthiërs 7:10). Hy het beslis 'n hoë waardering daarvoor gehad en dit word vir ons veral ook duidelik uit gedeeltes soos I Timotheus 4:4; Efesiërs 5:22-25 en II Korinthiërs 11:2.

Wie hierdie genadegawe nie het nie, moet trou en nie probeer om deur eie insig en deur eie krag ongetroud te bly nie. Só ' $n$ persoon verkeer dan in groot gevaar om in hoerery te verval.

Tog moet die persoon wat die genadegawe van onthouding besit altyd onthou dat dit 'n gawe van God is, en dat hy geen rede het om op diegene neer te kyk wat hulle nie kan onthou nie. Dwarsdeur Paulus se gedagtegang tref ons ook niks hiervan aan nie.

\section{Konklusie.}

Die genadegawes wat aan enkele lidmate van die gemeente geskenk is, moet gesien word as geestelike gawes van die nuwe aión, wat geskenk is nóg vóór die voleinding van die heilswerk van God. „Deze zijn een anticipatie van Godswege op het nog uitstaande, eschatologische heil" sê F. J. Pop. ${ }^{73}$ Reeds nou het God iets uitgedeel van die onvoorstelbare heerlikheid van die komende vrederyk. Die vorm waarin hierdie gawes verskyn vertoon iets van die ryk van God - die lig van hierdie ryk skyn daarin oor die gemeente. Die werklikheid van die koninkryk van God is hierin merkbaar naby; iets van die toekoms tree reeds in verskyning.

75. F. J. Pop, a.w., bl. 16. 